\title{
Christians reacted differently to non-Christian cults
}

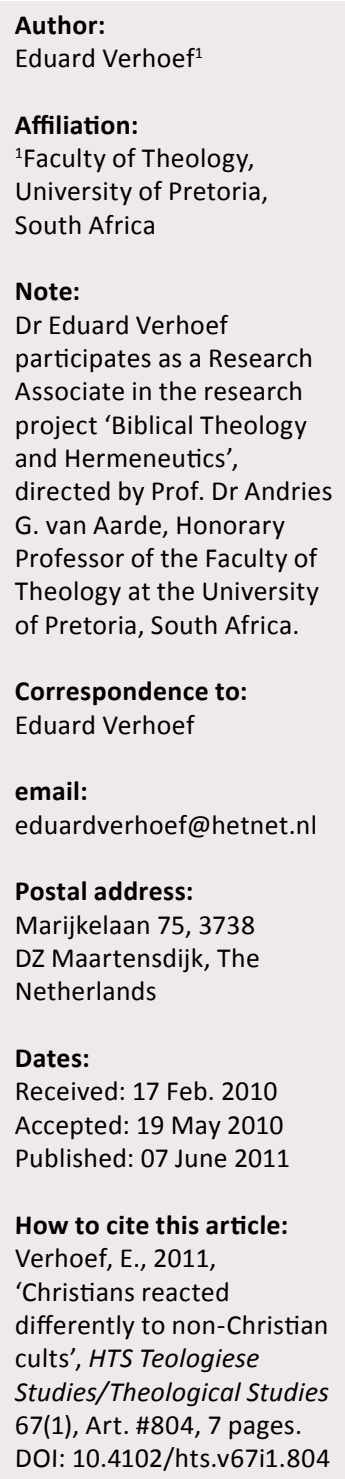

(C) 2011. The Authors. Licensee: OpenJournals Publishing. This work is licensed under the Creative Commons Attribution License.
Christians were confronted with many other religions during the expansion of Christianity. What was their attitude towards these other religions? Apparently Christians reacted very differently. Earlier I argued that the Christians in Philippi adopted some elements of the cult of Euephenes, an initiate in the Kabeiric cult of Samothrace. The Kabeiric cult was very much present in Thessalonica as well. In this article I argued that, here too, Christians took over some elements of the Kabeiric cult. In some other cities non-Christian cults were eliminated. These different reactions towards other religions and cults seemed to stem from the local situation. In particular, local religious customs seem to have been adopted and to have taken precedence over well-known national or even international religions. Apparently, it was very difficult for people to abandon strong local rituals.

In 1997, Andries van Aarde and Sanrie van Zijl published a very interesting article in which they drew attention to the pagan Hellenistic background that may have played a role in the development of Christology. Though more aspects should be taken into consideration it is self-evident to me that the entire history of the Christian church can be understood only against the background of the whole contemporary world. For example, Christians reacted very differently to non-Christian cults after they had assumed power in the Roman Empire. Sometimes temples and shrines were devastated, sometimes they were reused as churches. And sometimes elements of other cults were adopted in a more or less Christianised form. Recently I argued that in Philippi the cult of Euephenes, an initiate in the cult of the Kabeiroi on Samothrace, was succeeded by the veneration of Paul.

In the present article, however, I focused on the cult of Kabeiros in Thessalonica and its impact on the cult of Demetrios that was already thriving there, whereby the latter cult began to incorporate elements of the former. I concluded the article with short remark about the way Christians elsewhere adopted or rejected other cults, touching on the question why, in some cases, an older cult was integrated into the Christian cult and why it was terminated in other cases.

\section{Thessalonica and the cult of Kabeiros}

In 1950, Bengt Hemberg wrote a thorough study about the cult of Kabeiros (singular) and of the Kabeiroi (plural). In it, he collected many data regarding the cities where this cult played a role. It is clear from Hemberg's study that there were several differences in the way the Kabeiroi were venerated in these cities. In Thessalonica, the cult of one Kabeiros (Hemberg 1950:208 speaks about eine Sonderentwicklung and Witt ${ }^{1}$ 1985:975 speaks about 'Kabeiric monotheism') played a significant role next to other cults, such as those of Isis, Dionysos and others (cf. Steimle 2008:79200; Vom Brocke 2001:115-142).

The first mention of Kabeiros, with respect to Thessalonica, is on local coins. Kabeiros was depicted on these so-called pseudo-autonomous or provincial coins from the reign of Vespasian through the reign of Claudius Gothicus, who reigned CE 268-270 (cf. Touratsoglou 1988:86, 325-337). ${ }^{2}$ Accordingly, Kabeiros must have been assessed as an important god from the time of Vespasian, ${ }^{3}$ and even decades earlier, because of the process that must have preceded the coinage with his picture. But even before that time, Kabeiros may have been known in Thessalonica, as he was venerated in Larisa in the 2nd century BCE at the latest, and, as early as in the 5th century BCE in Thebes (Hemberg 1950:159, 189-190). ${ }^{4}$ From the reign of Septimius Severus (CE 192-211) onwards, Kabeiros was mentioned on imperial Thessalonian coins as well. These coins had the portraits of the Roman emperor and Kabeiros (Touratsoglou 1988:201-314). Most often, Kabeiros

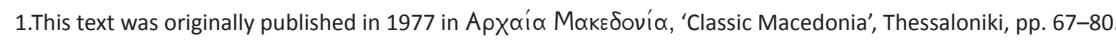

2.The mint of Thessalonica was closed for some time after the death of Claudius Gothicus due to the chaos in the Roman Empire.

3.This promotion does not necessarily mean that Kabeiros 'lost contact with the lower classes' (see Jewett 1986:131 citing R.M. Evans; see also Koester 2007:40)

4.See Pausanias IX.25 for Thebes. For this cult in Greece, see Hemberg (1950) and Baege (1913:175-180). 
is rendered with a hammer in his left hand and a rhyton in his right hand, wearing a short chiton, with a coat on his shoulder (Touratsoglou 1988: pictures 49-52).

Lactantius and Firmicus Maternus, writing in the 3rd and 4th century CE, respectively, both state that Kabeiros was worshipped in Thessalonica. ${ }^{5}$ Firmicus Maternus argued that this Kabeiros was murdered by his brothers and that he was venerated by the Thessalonians. He was assessed to be the 'tutelary deity' (Edson ${ }^{6}$ 1985:925). This role as tutelary deity becomes clear as Kabeiros is portrayed standing on the city wall (Touratsoglou 1988:309 and plate 45). In CE 254 and CE 268 the Goths had attacked Thessalonica and both times the Roman army had managed to drive them away. On a coin, perhaps issued by Claudius Gothicus in CE 269 (cf. Arrigoni 2003:20; Hemberg 1950:206), it says 'Deo Cabiro', in honour of God Kabeiros. These words might refer to these victories (Witt 1977:976). The rescue of the city was thought to have been achieved by Kabeiros (Vitti 1996a:92). Holy games were held in honour of Kabeiros from the time of Gordianus III

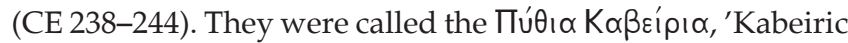

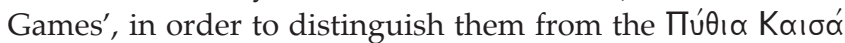
$\rho \varepsilon ı \alpha$, 'Caesar's Games', (Steimle 2008:163; Vacalopoulos 1963:14; Hemberg 1950:206-207). In the Octagon, part of Galerius's palace in Thessalonica, a marble capital has been found that shows Kabeiros in a short chiton and with a rhyton in his right hand (Tzanavari 2003:230). This rhyton could suggest that some elements of the cult of Dionysos had been adopted. One of the Kabeiroi may even have been known by the name of Dionysos (Vitti 1996a:91). Three other capitals in this palace depict Zeus, Hygeia and one of the Dioskouroi (Vitti 1996a:212, pictures 61-64). The capital with the sculpture of Kabeiros confirms that he had a prominent place in Thessalonica.

Kabeiros is mentioned in some inscriptions as well, one of which was written on a marble altar that was found nearby the monumental church of Saint Demetrios. This altar dates from the 3 rd century $C E$, and was nearly 2 metres high, about 41 centimetres wide and 22 centimetres thick. Someone is

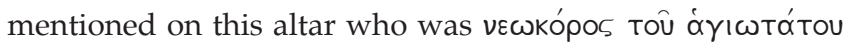

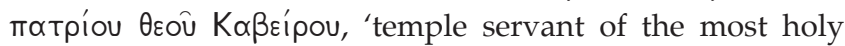
ancestral god Kabeiros' (Edson 1948:925-926, 1972:83-84, inscription 199). According to Touratsoglou, this heavy

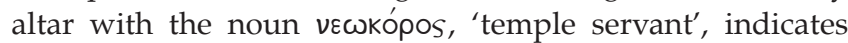
that a temple for Kabeiros must have been located in this area (Touratsoglou 1985:76; cf. Tzanavari 2003:230; Vitti 1996a:92.117; Theocharidis 1980:80). Apparently this temple servant was a high official, because he held the office of a magistrate as well. It is worth mentioning here that Kabeiros is depicted standing in a small temple on several coins from the 2 nd and the 3 rd century CE (see e.g. Touratsoglou 1988:206-208, 279, 305, 313; plates 23-24, 40, 45-46). Another inscription from the 3 rd century mentions someone who was

5.Lactantius, Divinae Institutiones I.15.8 ; Firmicus Maternus, De Erratione Profanarum Religionum 11.

6.This text was originally published in 1948 in the Harvard Theological Review 41, 153-204.

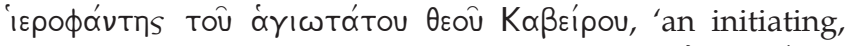
teaching priest of the most holy god Kabeiros', and 'o $\gamma \omega \nu \circ \theta^{\prime} \varepsilon$ tns, 'organiser of games' (Steimle 2008:159). Consequently, at least two different functions were connected with the cult

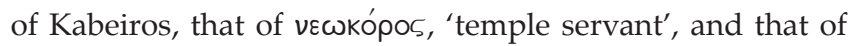
iєpoфóvтns, 'initiating, teaching priest'. These inscriptions confirm that Kabeiros was highly esteemed in Thessalonica in that time.

Maria Lagogianni published a 2nd century inscription, in

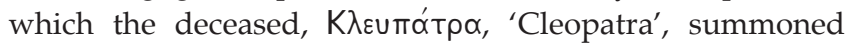

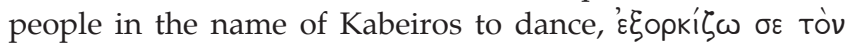

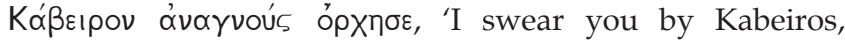
after reading this, to dance a while' (Lagogianni 1998:77, inscription 83). ${ }^{7}$ This inscription was found in Thessalonica, at Monastiriou 131, to the west of the western city wall, an area that may have been a graveyard. Very often, tombstones have been found at main roads outside the cities.

A fourth inscription should be mentioned here: in Agios Mamas, about 80 kilometres south-east of Thessalonica, a 3rd century inscription was found on a herm. It was dedicated to Kabeiros and to his son (Demitsas ${ }^{8}$ 1988:630, inscription 752). This inscription mentions Herennius Orestinus, a well-known citizen of Thessalonica (cf. Edson 1972:160, inscription number 488). He was the son of Orestinus, the iعpoфóvтns, 'the initiating, teaching priest'. This herm was probably related to a temple of Kabeiros (Hemberg 1950:170 171). ${ }^{9}$ It is worth mentioning here that Kabeiros and his son were venerated in Thebes as well (Hemberg 1950:191-192).

It is clear from the occurrences of the name of Kabeiros that the cult of Kabeiros played an important role in Thessalonica in the first centuries of the Common Era, next to other cults (cf. Steimle 2008:7-200; Vom Brocke 2001:113-142). Unfortunately we do not have much information about this cult there. The altar found in the neighbourhood of the Agios Demetrios certainly had a function related to sacrifices. The call to dance indicates that dancing belonged to the rites of the Kabeiric cult and it is clear that some feasts were organised in honour of Kabeiros.

The cult of the Kabeiroi is most often associated with the island of Samothrace. Lemnos, Imbros and Delos could be mentioned as well (cf. Blakely 2006:36-37), but, apparently, the cult centre on Samothrace was the most influential. There, the so-called Anaktoron was excavated, among other buildings. This was the hall where people were initiated into the Samothracian cult. The doors between the main hall of the Anaktoron and the inner sanctuary were flanked by the Kabeiroi (Lehmann 1966:47). It was indicated in an inscription written in Latin and in Greek that only the initiated were allowed to enter this inner sanctuary. Elements that played

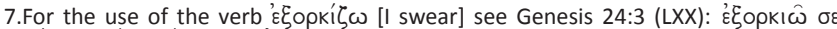
kúpıov Tò Asò Toû oupavou, 'I swear you to the Lord, the God of heaven'. A

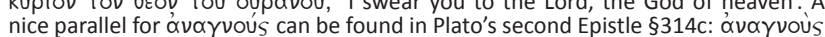
katók@uбov, 'when you have read this, burn it'.

8.This text was originally published in 1896 by Perri, Athens.

9.Cf. Feissel and Sève (1979:299). 
a role in the initiation and in reaching the degree of epopteia, the highest grade of initiation, in another building, the Hieron, were for example ritual dances (Lewis 1959:97-98, inscriptions 215-217), confession of sins, purification (Lewis 1959:111-112, inscriptions 239-240) and a symbolic baptism in blood (Lehmann 1966:33-35; cf. Witt 1977:968-969). Animals were slaughtered on this occasion (cf. Ex 24:8). It goes without saying that these rites remind us of Jewish and Christian rites and though we do not know if all of these elements were performed in Thessalonica, we can imagine that Thessalonian people acquainted with the Kabeiric rites recognised certain elements in the Christian cult. And the fact that Kabeiros was understood to save people even after he was murdered made it probably easier to understand the Christian message that Christ gave salvation to his adherents even after he died on the cross.

Another city where the Kabeiric cult is demonstrable is Thebes. It is even suggested that the buildings on Samothrace influenced the style of a temple in Thebes (Lehmann \& Spittle 1960:65-66). The Kabeiric cult probably played a role in Amphipolis as well (cf. besides the inscription mentioned above, Papastavru 1936:54, 97). In Philippi, a certain Euephenes was venerated who was an initiate in the Kabeiric cult on Samothrace (Verhoef 2008:701). However, as with Thessalonica, little information is known regarding the activities of these cults in Amphipolis and in Philippi.

We can affirm the connection between the Thessalonians and the cult on Samothrace on the basis of the following arguments:

- Firstly, there is an inscription from Samothrace that mentions a citizen from Thessalonica, Archepolis the son of Archepolis, as $\mu$ úotns, 'an initiate' (Fredrich 1909:63, inscription number 195). This inscription can be dated around the beginning of the Common Era.

- Secondly, in another inscription, dated to the 2nd or 3rd century CE, several persons from Thessalonica are mentioned as initiates in the cult of Samothrace (Chapouthier 1936:234, footnote 4; Dimitrova 2008:100).

The name of Kabeiros, or of the Kabeiroi, is not mentioned in these two inscriptions. Nevertheless, in my opinion, we can be certain that the Kabeiroi were venerated there, though the relation between the Kabeiroi and Samothrace has not yet been clarified. A problem is that, until now, the singular, Kabeiros, or the plural, Kabeiroi, have not been found on Samothrace (Cole 1984:1). According to Collart, the faithful people on Samothrace, and maybe on nearby Lemnos as well, did not like to pronounce the name of their deities, they simply said 'the great gods' or 'the gods' (Collart 1954:180). In any case, a connection between the Kabeiroi and Samothrace can be established on the basis of the following texts:

- A certain Euephenes is mentioned in an unpublished inscription that was found in Philippi as an initiate into the mystery cult of the Cabiri at the Sanctuary of Samothrace' (Koukouli \& Bakirtzis 1995:54; cf. Pilhofer 2009:393).
- A list is given of initiates of the temple of the Kabeiroi in an unpublished inscription from Samothrace (Pelekanidis 1978b:395).

- A third important inscription probably originates from Amphipolis. It is an epitaph dated after the 2nd century BCE (Karadima-Matsa \& Dimitrova 2003:335-338). In this inscription a connection is made between the Kabeiric cult and the cult of Demeter in Eleusis. It is said that a certain Isidoros, the son of Nikostratos, ${ }^{10}$ saw as an initiate the double holy light of Kabeiros among the Samothracians and the holy rites of Demeter in Eleusis. The mention of just one Kabeiros in this inscription is striking, as the plural Kabeiroi is used most often. We saw that just one Kabeiros was venerated in Thessalonica in Roman times.

- The fourth text is by Plutarch. He referred in Marcellus

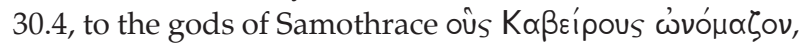
'that they called Kabeiroi', which they called Kabeiroi.

- As fifth statement I mention Herodotus, who said in

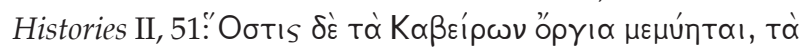

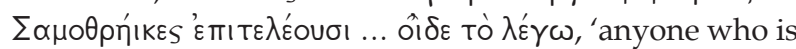
initiated in the rites of the Kabeiroi that the Samothracians perform ... knows what I mean'. ${ }^{11}$

We can conclude with certainty that the Kabeiroi had a function on Samothrace. And, as was argued above, there were several connections between the Thessalonians and Samothrace. Some citizens from Thessalonica were initiated in the Samothracian cult. Witt calls them 'Kabeiric Mystes' (Witt 1977:968).

We conclude that Kabeiros was worshipped as the tutelary deity of Thessalonica and that he was honoured in the Kabeiric games in the 3rd century of the Common Era. We can deduce from coins and from the inscriptions mentioned above that there was a temple connected with this cult. This temple was probably situated in the area where the Church of Agios Demetrios was later built. There were connections between Kabeiros and Samothrace. Some elements from the cult of the Kabeiroi on Samothrace are reminiscent of some aspects of the Christian cult. People acquainted with the cult of Kabeiros, or of the Kabeiroi, will have recognised well known elements in the Christian cult.

\section{The cult of Demetrios}

With respect to the cult of Demetrios we have the first and the second collection of the Miracles as the most imporant literary sources (for the text and a paraphrase see Lemerle 1979:47241 and for the text next to a translation in modern Greek, see Bakirtzis 1997:50-333; the text of these collections is subdivided in paragraphs that have, together, one consecutive numeration). The first collection of the Miracles is composed by John, archbishop of Thessalonica, in the beginning of the 7th century CE. The author of the second collection is unknown. Besides these, the two passions of Demetrios,

10.Not Isidoros Nikostratou, as Karadima-Matsa and Dimitrova (2003:337) seem to think.

11.For other authors who made a connection between Samothrace and the Kabeiroi, see Lewis (1959:63-88). 
known as Passio prima and Passio altera can be mentioned (for the Greek text of the Passio prima see Delehaye ${ }^{12}$ 1975:259263 , for the same text with a translation in modern Greek, see Bakirtzis 1987:28-35 and, for an English translation, see Skedros 1999:155-157; for the Greek text of the Passio altera with a translation in modern Greek, see Bakirtzis 1987:34-47 and, for an English translation, see Skedros 1999:149-154). These two writings offer some fascinating details, but their historical reliability is rather weak (Lemerle 1979:10, they have 'en commun leur insignifiance historique', 'they are both historically insignificant'). ${ }^{13}$

These documents provide many data, though they sometimes contradict each other. They say that Demetrios lived at the end of the 3rd and in the beginning of the 4th century CE. He was a brave soldier in the time that Galerius, Caesar of Illyrium and Thrace, was seated as Augustus in Thessalonica (i.e. around the year 305). Demetrios is even said to have been a proconsul (see Passio altera §2 in Bakirtzis 1997:36). He converted to Christianity and became a zealous defender of the Christian faith. Christianity was still forbidden at the time and Demetrios was imprisoned in the kilns of the public baths after some intrigues and Galerius had him killed there by his soldiers shortly after (see the Passio prima in Bakirtzis 1997:28-35). At night, friends of Demetrios would have looked for his body and have covered it with a mound of earth in order to protect it against beasts of prey. Faithful people are said to have often visited this place. They perceived that miracles happened there and that people recovered from their illnesses apparently because Demetrios had been buried there. In the following decades Demetrios's fame continued to grow.

Galerius died in 311 and, a few years later, Christians had received permission to practise their own religion. According to tradition, it was shortly after these events that Christians brought into use part of the public baths for their meetings around the martyr's body (Passio prima $\$ 7$ in Bakirtzis 1997:32.34). Tradition has it that they built a small church at the place where the body of Demetrios was supposed to lie in the ground. Later on, a certain Leontios, eparch (governor) of Illyricum had fallen ill and was brought to this holy place. Leontios begged Demetrios for recovery. He subsequently recovered and ordered a beautiful, larger church to be built as substitute for the rather small room for worship. This new church was situated between the public baths and the stadium according to the Passio altera $\$ 15, \mu \varepsilon \dot{\varepsilon} \sigma 0 \mathrm{v}$

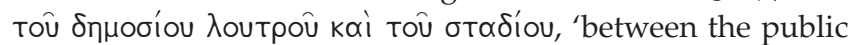
bathhouse and the stadion' (Bakirtzis 1997:44). According to the relevant texts the stadium was situated close to the Roman baths (Vickers 1971:339-340). Actually these baths were constructed by converting an older gymnasium (Vitti 1996a:54, 98-99) and would later be called the baths of Saint Demetrios. Some scholars argue over whether the stadium

12.This text was originally published in 1909 by Alphonse Picard, Paris.

13.There are other, less important, writings regarding Demetrios; for these see Lemerle (1979:9-12). was located north or south of the Roman baths, but a location south of these baths is more probable, because, among other reasons, this lightly sloping area was much more appropriate to build the stands than the steep area to the north (see Vickers 1971:341-342; Vitti 1996a:96-98 and 1996b, map 7). ${ }^{14}$

Who was this eparch Leontios? This question cannot be answered definitely. A Leontios is mentioned as eparch of Illyricum for the year 412-413 in the Codex Theodosianus (Mommsen 1954:322, 706). But the church of Demetrios is most often dated to the second half of the 5th century and the beginning of the 6th century (Bakirtzis 1995:60). Vickers mentioned a prefect of Constantinople in 434-435 with the name Leontios and argued that this Leontios was 'probably' the Leontios mentioned in the Passio prima and the Passio altera (Vickers 1974:347). Price (1999:168) opted for this Leontios to have had this church built without any argument. However, as far as we know, this Leontios did not hold the office of eparch in Illyricum. Spieser pointed to an eparch Leontios who was in office in 510 and he proposed, as an hypothesis, that it was this Leontios who had this church built (Spieser 1984:214; cf. Cormack 1989:549 argued: 'around $\left.500^{\prime}\right)$. However, in my opinion, this is rather late. As the emperor Justinian (527-565) asked for a relic of the famous Saint (Miracles $\$ 53$ in Bakirtzis 1997:118) it must have been a well-known cult that was celebrated in the Church of Agios Demetrios.

Another important factor is that a cruciform reliquary was found and an apse was discovered under the altar of the Agios Demetrios during excavations. It was argued that this apse originally belonged to the Roman baths and that it later formed part of an earlier church, rather than the church built in the second half of the 5th century (Soteriou \& Soteriou 1952:58-61; cf. Lemerle 1953:670; Lemerle 1981:206-218). The fact that the width of the present day narthex is only three aisles of the five-aisle church could be seen as an argument that a smaller, three-aisle, church once existed there.

The following reconstruction cannot be proven, but is arguable: Leontios, the eparch of Illyricum in 412-413, had a three-aisle church built in Thessalonica, and, after 441, as the seat of the prefecture was moved to Thessalonica, a new, larger five-aisle church was built in the place of the threeaisle church of Leontios (see Skedros 1999:38; Soteriou \& Soteriou 1952:246-247; cf. Popović 1987:112-115). This would fit in with the 'period of building activity, which saw the erection of monumental Christian buildings in Thessalonica after 441/442' (Skedros 1999:37), as the seat of the prefecture was moved from Sirmium to Thessalonica. This reasoning tallies with the data that archaeologists found with respect to the architecture and style of the church as we know it. Authors such as Kautzsch (1936:75) and Kleinbauer (1970:40, 44) make use of these architectural and stylistic aspects, both concluding that the current Church of Agios Demetrios was built in the second half of the 5th century (cf. Soteriou \&

14.Later on, Vickers argued for the identification of the stadium and the theatre; see Vickers (1974:348, n. 69). 
Soteriou 1952:247). This was some decades before Justinian asked for some relics of the then famous Saint. In any case, it is significant for us, to know that the cult of Saint Demetrios was practised at least since the end of the 5th century, and maybe some decades earlier at the place where the church had been built not long before. Data with respect to Leontios, and regarding the life of Demetrios himself, are much less certain.

Paul Lemerle (1981:13-26) gave an overview of the many studies regarding the stories about Demetrios and his cult. He mentioned among others, H. Gelzer (1899:53-54) who argued: 'Das ganze Christentum der Thessalonicher besteht nur in Demetrioskult. Christus wird nur noch honoris causa genannt', 'whole Christianity is only worship of Demetrios and Christ is menioned only honorarily'. This statement is certainly exaggerated. But we can easily see that Demetrios was a prominent figure in the Christian church of Thessalonica. Holy water played a role in the veneration of Demetrios (Grabar 1946:453). The water was supplied from a well in the northeast of the church and was channelled through plumbing conduits to a holy basin in the so-called crypt. This is the place where, according to tradition, Demetrios was murdered and buried. Water taken from this place was considered holy and medicinal. Worshippers came here to venerate Demetrios and to take some of this holy water to be cured from their diseases.

Water also played an important role in the cult in Philippi (Verhoef 2008:704). Bakirtzis argued that there were

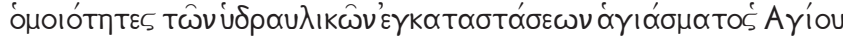

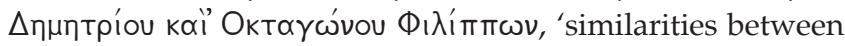
the hydraulic system of Saint Demetrios' shrine and that of the Octagon in Philippi' (Bakirtzis 1997:505). But there are more examples of cults where water was used for peculiar rituals. Euripides knew of purification by washing with water before sacred rituals; see Euripides's Ion 96-97; Heracles 928 and see the orator Aeschines's Oratio in Ctesiphontem 403a-b (Dilts 1992:146-147; cf. Davis 2001:114-120; Martin 1951:164). There are differences with respect to Philippi and Thessalonica as well. We can trace a seamless transition from the Euephenes cult into the cult of Paul in Philippi, but the development in Thessalonica was different. We do not know when exactly the Kabeiric cult dwindled, but it seems probable that there was a gap of some time between the cult of Kabeiros and that of Demetrios. Afterwards oil was used as well in the cult of Demetrios (Bakirtzis 1997:504-505). Demetrios's grave was thought to possess miraculous power. ${ }^{15}$ The sacred relic that was supposed to be in a chest in the Church of Agios Demetrios, gave 'an inexhaustible stream of divine perfumes which had therapeutic properties' (Vacalopoulos 1963:22).

This phenomenon is, in itself, not unheard of. We also know of other cities where martyrs were venerated and where people could take holy water or oil in ampullae in order to partake in the martyr's power (cf. Davis 2001:46.176-177; Kötting 1980:192).

15.Cf. 2 Kings 13:21, which says that a dead man came to life again as his body touched Elisha's bones.
Besides the miraculous recoveries that Demetrios caused, he had another task - that of protector of Thessalonica. In the chaos of the second half of the 5th century onwards, Thessalonica was besieged several times by the 'barbarians', but it was believed that Demetrios managed to repulse the attacks time and again. He was honoured several timesin the Miracles with honorary titles such as фıло́то $\lambda_{1 s}$ [loving

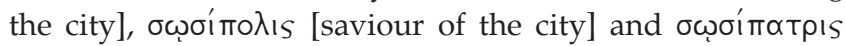
[saviour of the fatherland]; see, for example, Miracles §41, $\S 210, \S 220$ in Bakirtzis (1997:100, 258, 264). Interesting, in this respect, are descriptions of Demetrios appearing on the city

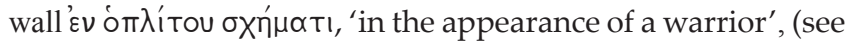
$\S 120$ of Miracles in Lemerle 1979:135; Bakirtzis 1997:184 and pictures 6, 9, 11-18, 21 after page 496 in Bakirtzis's book).

We conclude that Demetrios was venerated as a miraculous healer at least from the second half of the 5th century onwards. Many people visited the church of Agios Demetrios in the hope to be cured from their illnesses. Moreover, Demetrios was revered as protector of Thessalonica. His fame was so widespread that Byzantine emperors tried to acquire some of his relics.

\section{The cult of Demetrios assumed some Kabeiric cult elements}

According to Lucius 'ist Demetrios nur dadurch zu Macht und Ansehen gelangt, dass er ein besonders wertvolles Erbe in seiner Vaterstadt angetreten hat', 'Demetrios managed to achieve power and status only because he inherited an especially valuale estate in his home town' (Lucius 1904:221). Tafrali expressed himself even stronger: 'ce fut saint Démétrius qui remplaça le Cabire comme protecteur et patron de la ville', 'it was Saint Demetrios who replaced Kabeiros' (Tafrali 1919:52; cf Theocharidis 1980:80). According to Edson, Kabeiros was 'the forerunner' of Demetrios (Edson 1948:925.936). We can see that the church of Agios Demetrios was built in the area where the cult of Kabeiros is understood to have been practised. And both Kabeiros and Demetrios had the function of protector of Thessalonica. Besides the function of protector of Thessalonica, Demetrios was given even more power than was ascribed to Kabeiros (Lucius 1904:224; Vacalopoulos 1963:22). The role of Kabeiros had been restricted to the city and its inhabitants, while Demetrios was a saviour for foreigners as well. Consequently the veneration of Demetrios spread to other cities like for example Sirmium. ${ }^{16}$

We can also see some similarities in the way Kabeiros and Demetrios are depicted: young, without a beard and with a short chiton. We know the appearance of Kabeiros from coins of Thessalonica and from the capital in Galerius's palace (Touratsoglou 1988: pictures 49-52; Tzanavari 2003:230). Similar pictures from Demetrios are dated to the 11th century and later, but it can be argued that these pictures go back to older representations. Lemerle thoroughly studied the

16.Sometimes it is argued that the veneration of Demetrios originated in Sirmium. But see Lemerle (1981:202); Skedros (1999:27-29). 
traditions regarding the Miracles of Demetrios, drawing attention to some remarks in these narratives. Apparently different categories of representations were known. In the first collection of the Miracles of Saint Demetros $\$ 167$ it says that Demetrios is seen just as he is depicted ' $\varepsilon \nu$ Tôs $\alpha \rho x \propto เ о т \varepsilon$

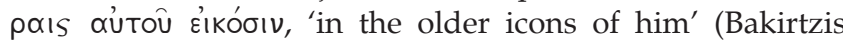
1997:224; Lemerle 1979:162). Demetrios is described there with an angelic face, with the skin of his face said to be luminous like the sun (cf. Bakirtzis 1997: picture 7 after page 432). Other descriptions are very different, such as Demetrios appearing on the city wall ' $\varepsilon \nu$ om $\lambda$ ítou $\sigma x \eta \dot{n} \mu \mathrm{Tl}$, 'in the appearance of a warrior' (see \$120 of the Miracles in Lemerle 1979:135; Bakirtzis 1997:184, pictures 6, 9, 11-18, 21 after page 496 in Bakirtzis's book; cf. Walter 2003:71) ${ }^{17}$ and Demetrios as a captain of the Greek army on horseback in a short cloak in $\S 161$ and $\S 165$ (Lemerle 1979:157-158; Bakirtzis 1997:218, 220 and pictures 4, 23, 24 after page 496 in Bakirtzis's book; Walter 2003:71). The descriptions of the warrior, especially, are very much like those of Kabeiros on the coins mentioned above and on the capital found in Galerius's palace.

Witt (1977:976) suggests that the name 'Kouber', used, for example in the Miracles \$286 (Bakirtzis 1997:308) for a Bulgarian warrior, would refer to 'the rivalry between the now ousted pagan champion and his successor, the Christian Saint' (Witt 1977:976). But we do not have any evidence for this statement (cf. Lemerle 1981:143-150). Moreover, Kouber was a common name in that area, so we do not need to look for a particular reason for the use of this name in the Miracles.

We conclude that there are similarities between the Kabeiric cult and the later veneration of Demetrios. The conclusions by Lucius and Tafrali, mentioned above, are too far-reaching in my opinion. Currently we do not have sufficient data to conclude that the veneration of Demetrios is dependent on the Kabeiric cult, but we can state that some elements of the older cult have been assumed in the younger cult (cf. Touratsoglou 1985:76). As I argued above, there may have been a gap of some time between the fading away of the cult of Kabeiros and the beginning of the cult of Demetrios.

\section{Christians reacted differently to other cults}

Several authors wrote about the reactons of Christians to non-Christian cults and rituals in the 4th century and later. The letters of Emperor Julianus (361-363) are well-known. In one of these he voiced his surprise when he was told that the Christians in Troy venerated their martyrs in a similar way as the Greeks venerated their heroes (Bidez 1924:86), which means that Christians there had assumed older rituals for the veneration of their martyrs. On the other hand, Julianus knew about violent actions against non-Christian temples as well. In

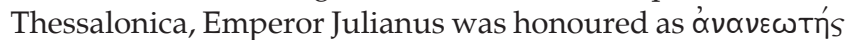

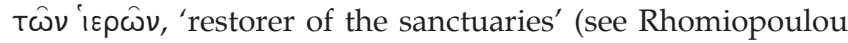
1981:304-305). From this statement, we can conclude that temples were devastated before his time. Sozomenos pointed

17.Similar statements can be found in the second collection Miracles $§ 188$ (Bakirtzis 1997:242; Lemerle 1979:178). to similar incidents in his Historia ecclesiastica when he wrote that Julianus exiled the bishop of Cyzikus because he had destroyed a temple and had defiled holy ground (Hansen 2004:620). Fowden (1978:53-78) mentions more examples of actions by bishops or monks and other Christians against temples and shrines in the eastern Roman Empire. ${ }^{18}$ In Kipia, a village in the territory of Philippi, the temple of the Heros Aulonitis was destroyed on purpose, possibly by Christians according to the archaeologists (Koukouli-Chrysanthaki 1985:266). A well-known example is the devastation of the Temple of Venus in Jerusalem in order to make place for the constrution of the Church of the Holy Sepulchre. The philosopher Libanius, who taught in Antioch, wrote his famous 30th Oratio probably in 386, in which he protested against the destruction of temples, sculptures and works of other art and against plundering by Christian monks (Norman 1977:100-150).

On the other hand, we know of many examples where older pagan shrines or temples were not destroyed, but were used as Christian churches after some adaptations. The so-called Rotunda in Thessalonica was probably originally used as a temple (Vitti 1996a:228; reluctantly Steimle 2008:71-72). The Parthenon in Athens may be the best-known example, though of a later date (cf. Orlandos 1994:264).

We see that Christians used their dominant position very differently in the second half of the 4th century and later, particularly after the laws issued by Theodosius II in 435 . There is a wide range of possibilities. The two extremes are the adoption of a shrine and elements of its cult on the one hand (cf. Davis 2001:75-77) and the destruction of a shrine or a temple on the other hand. What actually happened seems to be very dependent on accidental and local circumstances, with differing reactions even found within one community. The shrine of Euephenes in Philippi was left intact and certain elements of its cult were preserved, but the temple of the Heros Aulonitis in Kipia, within Philippi's territory, was destroyed. I conclude that local cults were sometimes very strong and, apparently, sometimes even stronger than well-known national or even international religions (cf. Price 1999:166; Trombley 2001:152-153).

\section{Acknowledgements}

I owe many thanks to Professor Van Aarde for the article mentioned above and for his many other scholarly publications that he managed to write in spite of his health problems. His publications are always provoking and he regularly sought the limits of what can be proven. His remarks on the Hellenistic background of New Testament documents were right on the mark.

I would like to thank Dr J.W. van Arenthals for her feedback on this text.

\section{References}

Arrigoni, M., 2003, 'Was Claudius really Gothicus?', The Celator 17(11), 14-20.

Baege, W., 1913, 'De Macedonum sacris', Dissertationes Philologicae Halensis XXII, 1 , Max Niemeyer, Halle.

18 . Fowden argues that the situation in the western Empire was different because of 'internal disorder and external invasion' (Fowden 1978: 57, 71-72). 
Bakirtzis, C., 1995, 'Le culte de Saint Démétrius [The cult of Saint Demetrios]', Jahrbuch für Antike und Christentum 20(1), 58-68.

Bakirtzis, C., 1997, АГIOY $\triangle$ HMHTPIOY $\Theta A Y M A T A$ [The miracles of Saint Demetrios], Agra, Thessaloniki.

Bakirtzis, C., 2002, 'Pilgrimage to Thessalonike: The Tomb of St. Demetrius', Dumbarton Oaks Papers 56, 175-192. doi: 10.2307/1291861

Bidez, J., 1924, L'empereur Julien. Oeuvres complètes [The emperor Julianus. Complete works], I.2. Les belles lettres, Paris.

Blakely, S., 2006, Myth, ritual, and metallurgy in Ancient Greece and recent Africa, Cambridge University Press, Cambridge.

Chapouthier, F., 1936, Les Dioscures au service d' une Déesse [The Dioscuri in service of a goddess], E.de Boccard, Paris.

Cole, S.G., 1984, Theoi Megaloi: The cult of the great gods at Samothrace, Études préliminaires aux religions orientales dans l'Empire Romain 96 [No translation available], Brill, Leiden.

Collart, J., 1954, Varron. De Lingua Latina, Livre V, Les belles lettres, Paris.

Cormack, R., 1989, 'The making of a patron Saint: The powers of art and ritual in Byzantine Thessaloniki', in I. Lavin, (ed.), World Art, vol. III, pp. 547-555, Pennsylvania State University Press, University Park.

Davis, S.J., 2001, The cult of St Thecla, Oxford University Press, Oxford.

Delehaye, H., 1975, Les légendes Grecques [The Greek legends], reprint, Arno Press, New York.

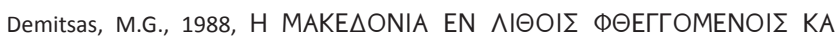
MNHMEIOI $\Sigma \Sigma \Omega Z O M E N O I \Sigma$ I-II [Macedon in inscriptions and in survive

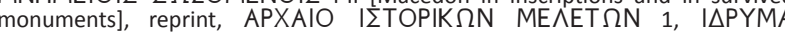
$M E \wedge E T \Omega N$ XEP $\Sigma O N H \Sigma O Y$ TOY AIMOY, Thessaloniki.

Dilts, M.R., 1992, Scholia in Aeschinem, Bibliotheca Scriptorum Graecorum et Romanorum, Teubner, Leipzig.

Dimitrova, N.M., 2008, Theoroi and Initiates in Samothrace. The Epigraphical Evidence, Hesperia, suppl. 37, American School of Classical Studies, Athens.

Edson, C., 1972, Inscriptiones Graecae Epiri, Macedoniae, Thraciae, Scythiae, Inscriptiones Graecae X(2.1), Walter de Gruyter, Berlin.

Edson, C., 1985, 'Cults of Thessalonica', reprint, in P. Adam-Veleni (ed.)

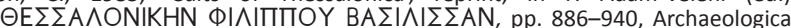
Museum, Thessaloniki.

Feissel, D. \& Sève, M., 1979, 'La Chalcidique vue par Charles Avezou (Avril-Ma 1914) [Chalcidice as seen by Charles Avezou (April-May 1914)]', Bulletin de correspondance Hellénique 103, 229-320.

Fowden, G., 1978, 'Bishops and temples in the Eastern Roman Empire AD 320-435', The Journal of Theological Studies 29, 53-78. doi: 10.1093/jts/XXIX.1.53

Fredrich, C., 1909, 'Inscriptiones Insularum Maris Aegaei praeter Delum' [Inscriptions from the islands of the Aegean Sea except Delos], Inscriptiones Graecae XII(8), Georg Reimer, Berlin.

Gelzer, H., 1899, 'Die Genesis der byzantinischen Themenverfassung', Abhandlungen der Königlichen Sächsischen Gesellschaft der Wissenschaften, PhilosophischPhilologischen Klasse 18(5), 1-133.

Grabar, A., 1946, Martyrium I. Architecture [The martyr's shrine. Architecture], Collège de France, Paris.

Hansen, G.C., 2004, Sozomenos. Historia Ecclesiastica [Sozomenos. Church history] Fontes Christiani 73, vol. 2, Brepols, Turnhout.

Hemberg, B., 1950, Die Kabiren, Almqvist \& Wiksells, Uppsala.

Jewett, R., 1986, The Thessalonian correspondence, Fortress, Philadelphia.

Karadima-Matsa, C. \& Dimitrova, N., 2003, 'Epitaph for an Initiate at Samothrace and Eleusis', Chiron 33, 335-45.

Kautzsch, R., 1936, Kapitellstudien, Studien zur spätantiken Kunstgeschichte 9, Walter de Gruyter, Berlin

Kleinbauer, W.E., 1970, 'Some observations on the dating of S. Demetrios in Thessaloniki', Byzantion 40, 36-44.

Koester, H., 2007, Paul \& his world, Fortress, Minneapolis.

Kötting, B., 1980, Peregrinatio Religiosa 2. Durchgesehene Auflage, Forschungen zur Volkskunde 33/34/35, Stendershoff, Münster.

Koukouli-Chrysanthaki, C., 1985, 'Kńmı - Akpoßoúvı [Kipia - Akrobouni]', APXAIO^OГIKÓN $\triangle$ E $\Lambda$ TIÓN 40, 263-266.

Koukouli-Chrysanthaki, C. \& Bakirtzis, C., 1995, Philippi, Ministry of Culture, Athens.

Lagogianni, M., 1998, Die Grabdenkmäler mit Porträts aus Makedonien, Corpus Signorum Imperii Romani. Griechenland III, 1, Akademie von Athen, Athens.

Lehmann, K. \& Spittle, D., 1960, Samothrace: Excavations conducted by the Institute of Fine Arts of New York University IV, 2. The Altar Court, Pantheon Books, New York.

Lehmann, K., 1966, Samothrace. A Guide to the excavations and the museum, 3rd edn., Augustin, Locust Valley.

Lemerle, P., 1953, 'Saint Démétrius de Thessalonique et les problèmes du martyrion et du transept', Bulletin de correspondance hellénique 77, 660-694.

Lemerle, P., 1979, Les plus anciens recueils des miracles de saint Démétrius I [The oldest collections of Saint Demetrios's miracles], Le texte, Centre national de la Recherche Scientifique, Paris.
Lemerle, P., 1980-1981, 'Note sur les plus anciennes représentations de Saint Démétrius [Remark regarding the oldest representations of Saint Demetrios]', $\triangle E \wedge T I O N$

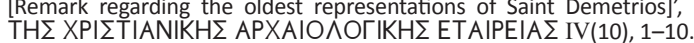

Lemerle, P., 1981, Les plus anciens recueils des miracles de saint Démétrius [The oldest collections of Saint Demetrios's miracles] II. Commentaire, Centre national de la Recherche Scientifique, Paris.

Lewis, N., 1959, Samothrace: The ancient literary sources, Samothrace I, Routledge \& Kegan Paul, London.

Lucius, E., 1904, Die Anfänge des Heiligenkults in der christlichen Kirche, Mohr, Tübingen.

Martin, R., 1951, Recherches sur l'agora grecqe [Investigations in the Greek agora], Bibliothèque des écoles françaises d'Athènes et de Rome 174, E. de Boccard, Paris.

Mommsen, T., 1954, Theodosiani Libri XVI cum Constitutionibus Sirmondianis [Sixteen books of Theodosius with the Sirmondian Constitutions] I.2, Weidmann, Berlin.

Norman, A.F., 1977, Libanius II, Harvard University Press, Cambridge.

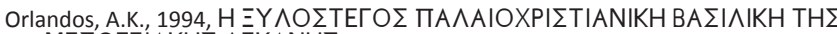
ME $\Sigma O Г E I A K H \Sigma \Lambda$ EKANH $\Sigma$ [The early wooden roofed Christian basilica around

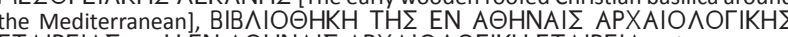

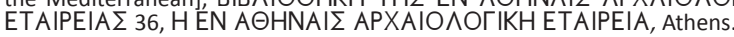

Pelekanidis, S., 1975, 'Kultprobleme in Apostel-Paulus-Oktagon von Philippi im Zusammenhang mit einem älteren Heroenkult', in Atti del IX Congresso Internazionale di Archeologia Cristiana II, pp. 393-397, Citta del Vaticano Pontificio Instituto, Rome.

Pilhofer, P., 2009, 'Philippi II. Katalog der Inschriften von Philippi', 2. überarbeitete und ergänzte Auflage, Wissenschaftliche Untersuchungen zum Neuen Testament 119 , Mohr, Tübingen.

Popović, V., 1987, 'Die süddanubischen Provinzen in der Spätantike vom Ende des 4. bis zur Mitte des 5. Jahrhunderts', Südosteuropa-Jahrbuch 17, 95-139.

Price, S., 1999, Religions of the ancient Greeks, Cambridge University Press, Cambridge.

Rhomiopoulou, K., 1981, 'New Inscriptions in the Archaeological Museum, Thessaloniki', in H.J. Dell, (ed), Ancient Macedonian Studies in Honour of Charles F. Edson, pp. 299-305, Institute for Balkan Studies, Thessaloniki.

Skedros, J.C., 1999, Saint Demetrios of Thessaloniki, Trinity International, Harrisburg.

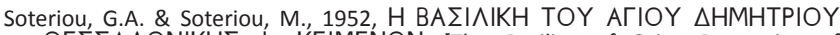
OE $\Sigma \Sigma A \wedge O N I K H \Sigma$ I, KEIMENON [The Basilica of Saint Demetrios of

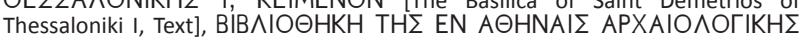

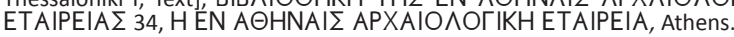

Spieser, J.-M., 1984, Thessalonique et ses monuments du IVe au Vle siècle [Thessalonica and its monuments of the 4 th to the 6th century], Bibliothèque des écoles Françaises d'Athènes et de Rome 254, E. de Boccard, Paris.

Steimle, C., 2008, 'Religion im römischen Thessaloniki', Studien und Texte zu Antike und Christentum 47, Mohr, Tübingen.

Tafrali, O., 1919, Thessalonique des origines au XIVe siècle [Thessalonica from the beginning until the 16th century], Ernest Leroux, Paris.

Theocharidis, G.I., 1980, IITOPIA TH $\Sigma$ MAKE $\triangle O N I A \Sigma$ KATA TOY $\Sigma$ ME $\Sigma O Y$ OY X'ONOY $\sum$ (285-1354) [History of Macedon from 285 until 1354], MAKE $\triangle$ ONIKH BIB 1 IO $O H K H 55$, ETAIPEIA MAKE $\triangle O N I K \Omega N \Sigma \Pi O Y \triangle \Omega N$, Thessaloniki.

Touratsoglou, I.P., 1985, 'TOY АГI $\Omega$ TATOY $\Theta E O Y$ KABEIPOY [Of the holiest god Kabeiros]', Thessaloniki 1, 71-83.

Touratsoglou, I., 1988, 'Die Münzstätte von Thessaloniki in der römischen Kaiserzeit', Antike Münzen und geschnittene Steine XII, Walter de Gruyter, Berlin.

Trombley, F.R., 2001, Hellenic religion and Christianization. C.370-529, vol. I, Brill, Leiden.

Tzanavari, K., 2003, 'The worship of Gods and Heroes in Thessaloniki', in D.V. Grammenos (ed.), Roman Thessaloniki, pp. 177-262, Archaeological Museum, Thessaloniki.

Vacalopoulos, A.E., 1963, A history of Thessaloniki, Institute for Balkan Studies, Thessaloniki.

Van Aarde, A. \& Van Zyl, S., 1997, ‘Die Lukaanse Jesusbeeld: In dialoog met Wilhelm Bousset se "Kyrios Christos"', HTS Teleogiese Studies/Theological Studies 53(1\&2), 185-208.

Verhoef, E., 2008, 'Syncretism in the church of Philippi', HTS Teologiese Studies/ Theological Studies 64, 697-714.

Verhoef, E., 2009, Filippi. Hoe het Christendom in Europa begon: Een gids door de opgravingen, Parthenon, Almere.

Vickers, M., 1971, 'The stadium at Thessaloniki', Byzantion 41, 339-348. doi: 10.1515/ byzs.1974.67.2.337

Vickers, M., 1974, 'Sirmium or Thessaloniki? A critical examination of the St. Demetrius legend', Byzantinische Zeitschrift 67, 337-348.

Vitti, M., 1996a, H ПO town development of Thessalonica], Archaeological Society, Athens.

Vitti, M., 1996b, H TO $\triangle$ EO $\triangle O M I K H E \equiv E \wedge I E H T H \Sigma \Theta E \Sigma \Sigma A \wedge O N I K H \Sigma$. XAPTE $\Sigma$ [The town development of Thessalonica. Maps], Archaeological Society, Athens.

Witt, R., 1985, 'The Kabeiroi in ancient Macedonia', reprint, in P. Adam-Veleni (ed.) OE $\Sigma \Sigma A \wedge O N I K H N$ ФI Museum, Thessaloniki. 